\title{
Novelties in the Diagnosis and Treatment of Angioedema
}

\author{
Cicardi M, Suffritti C, Perego F, Caccia S
}

\author{
Department of Biomedical and Clinical Sciences Luigi Sacco, University of Milan, ASST Fatebenefratelli Sacco, \\ Milano, Italy
}

J Investig Allergol Clin Immunol 2016; Vol. 26(4): 212-221

doi: 10.18176/jiaci.0087

\begin{abstract}
Angioedema is defined as local, noninflammatory, self-limiting edema that is circumscribed owing to increased leakage of plasma from the capillaries located in the deep layers of the skin and the mucosae. Two mediators, histamine and bradykinin, account for most cases of angioedema. Angioedema can occur with wheals as a manifestation of urticaria, and this form is frequently allergic. In the present review, we discuss nonallergic angioedema without wheals, which can be divided into 3 acquired and 4 hereditary forms. Histamine is the mediator in acquired angioedema of unknown etiology (idiopathic histaminergic acquired angioedema), whereas in other forms the main mediator is bradykinin. Angioedema can be caused by C1-inhibitor deficiency (C1-INH-hereditary angioedema and C1-INH-acquired angioedema), mutations in coagulation factor XII (FXII-hereditary angioedema), and treatment with angiotensin-converting enzyme inhibitors (ACEl-acquired angioedema). Etiology remains unclear in acquired angioedema (idiopathic nonhistaminergic acquired angioedema) and in 1 type of hereditary angioedema (hereditary angioedema of unknown origin). Several treatments are licensed for hereditary C1INH deficiency. Plasma-derived and recombinant C1-INHs, the bradykinin receptor blocker icatibant, and the plasma kallikrein inhibitor ecallantide have been approved for on-demand treatment to reverse angioedema symptoms. Attenuated androgen and plasma-derived C1-INH are approved for prophylaxis.
\end{abstract}

Key words: Angioedema. Bradykinin. Histamine. C1 inhibitor. Coagulation factor XII. Angiotensin-converting enzyme inhibitors. Urticaria.

\section{Resumen}

Angioedema se define como un edema local, autolimitado, no-inflamatorio. Se trata de un edema circunscrito debido a la trasvasación de plasma de los capilares localizados en los sustratos profundos de la piel y de las mucosas. En la mayoría de los casos están implicados dos mediadores, la histamina y la serotonina. Puede manifestarse en forma de habones como en la urticaria de origen alérgico. El angioedema de origen no alérgico es el motivo de esta revisión. Se puede presentar bajo 3 formas adquiridas y 4 formas hereditarias. La histamina es el mediador implicado en el angioedema adquirido de etiología desconocida (angioedema adquirido idiopático histaminérgico). En las otras formas se sospecha que es la serotonina el mediador principal. La etiología del angioedema puede ser identificado en 4 tipos: una deficiencia de C1-inhibidor (C1-INH-angioedema hereditario y C1-INH-angioedema adquirido), mutaciones en el factor XII de coagulación (FXII-angioedema hereditario), tratamiento con inhibidores del enzima convertidor de la angiotensina (ACEi-angioedema adquirido). En uno de los adquiridos (angioedema adquirido idiopático no histaminérgico) y en el hereditario de origen desconocido, no se ha identificado todavía su etiología. Varios tratamientos están aprobados para revertir los síntomas clínicos y se aplican en la deficiencia de angioedema hereditario por déficit de C1-INH: Derivados de plasma y C1-INHs recombinantes, icatibant como bloqueante del receptor de la bradiquinina y ecallantide como inhibidor de la kalicreina. Los andrógenos atenuados y los derivados plasmáticos de C1-INH se utilizan en la profilaxis de los ataques.

Palabras clave: Angioedema. Bradiquinina. Histamina. C1 inhibidor. Factor XII de coagulación. Inhibidores de la enzima convertidora de la angiotensina. Urticaria. 


\section{Introduction}

Angioedema is defined as local, noninflammatory, selflimiting edema that is a circumscribed owing to increased leakage of plasma from the capillaries located in the deep layers of the skin and the mucosae. The leakage depends on accumulation of endogenous inflammatory compounds that increase endothelial cell permeability without a fullblown inflammatory process. Hence, of the Celsus tetrad of inflammation (tumor, rubor, dolor, and calor) only tumor (edema) is characteristic of angioedema, thus confirming local accumulation of fluid and absence of inflammatory infiltrate [1]. This "limited inflammation" manifests clinically as the edema described above, which remits in no longer than 5 days with no residual damage. Persistent local cutaneous edema, such as the facial swelling that is characteristic of Melkersson-Rosenthal syndrome, should not be considered angioedema [2].

Angioedema frequently presents with other skin lesions, mainly wheals. These lesions result from increased capillary leakage caused by endogenous mediators, which, in this condition, act on vessels of the superficial skin layers. In wheals, rubor and calor, which are clinical manifestations of vasodilation, stand out over tumor, which is the clinical manifestation of plasma leakage [3].

Angioedema and wheals are cardinal symptoms of urticaria. The concomitant presence of the 2 lesions is either reported as urticaria-angioedema syndrome or simply as urticaria. This term is maintained when wheals occur without angioedema, although it should not be used for angioedema without wheals.

The approach to the patient with angioedema should take an additional 2 features into account, namely, acute onset of symptoms upon exposure to a specific trigger(s) (allergic, pseudoallergic, and physical) and chronic recurrence of symptoms not related to a specific trigger(s) (chronic spontaneous urticaria and angioedema without wheals) [4]. Nonallergic angioedema without wheals encompasses various conditions with differing etiology and pathogenesis, in which angioedema is the most substantial part of the disease [5] Nonallergic angioedema, which we consider primary angioedema, has only recently been classified and is the topic of this review (Figure 1) [6].

\section{Pathophysiology}

The mediators that induce endothelial cell permeability and their mechanisms of release are key elements in the diagnosis and treatment of primary angioedema. Vessel leakage and formation of edema depend on the integrity of the endothelial cell-cell junction and cell-surface expression of the transmembrane adhesive protein, vascular endothelial (VE) cadherin. Phosphorylation of VE-cadherin by tyrosine is a general mechanism involved in weakening of the endothelial cell barrier resulting from cell stimulation. It is likely that histamine and bradykinin, the 2 main mediators involved in angioedema, exert their permeabilizing effect mainly through phosphorylation of VE-cadherin $[7,8]$. Detection of soluble VE-cadherin in the serum of patients with a form of primary angioedema during an attack reinforces this view [9]. Phosphorylation of intracellular proteins requires generation of nitric oxide (NO) by endothelial cell NO synthase. Various transmembrane receptors enhance endothelial cell NO synthase, thus contributing to permeability. The 2 major factors that determine vascular permeability are blood flow and endothelial barrier function [10]. In the case of histamine, a recent study revealed that hyperpermeability is due mainly
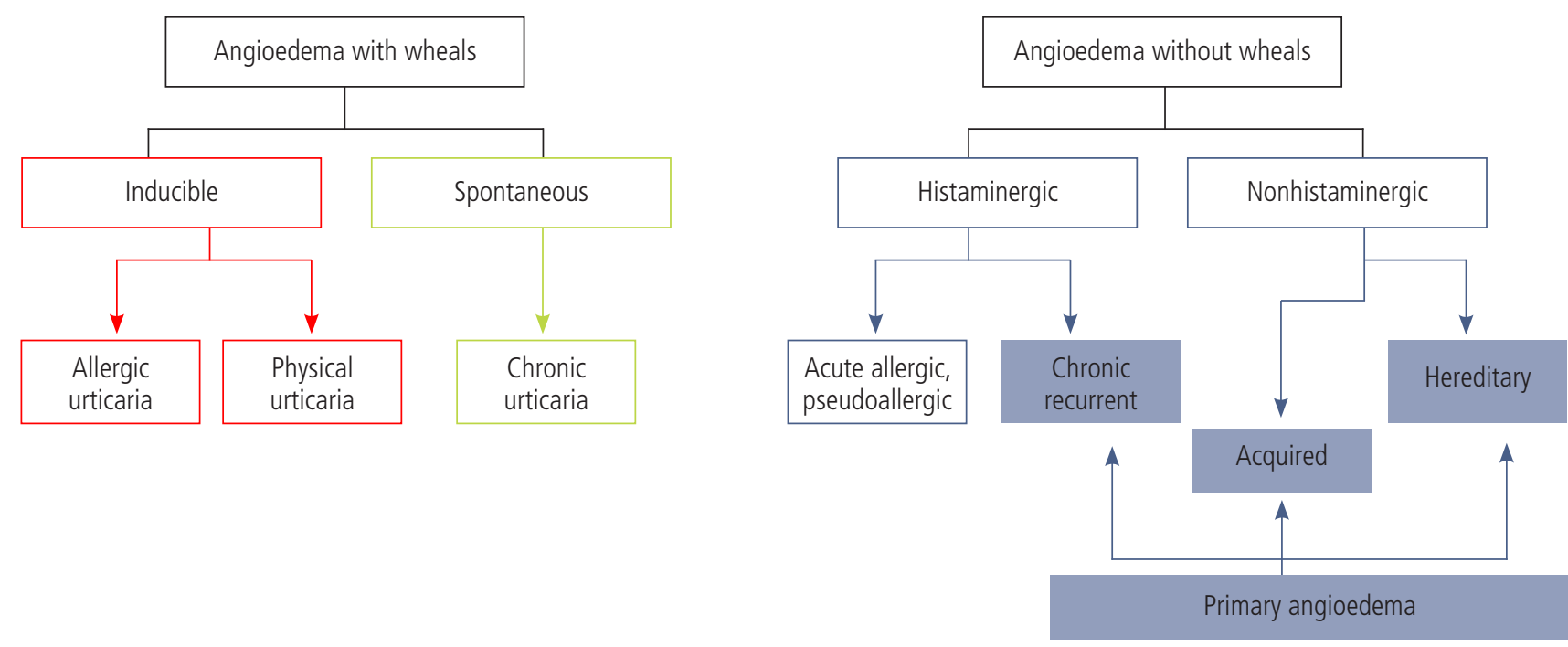

Modified from Wu et al [5].

Figure 1. Urticaria and angioedema. 
to the NO-induced increase in blood flow, which in turn is controlled by stimulation by vascular endothelial growth factor $[7,11]$. According to this finding, rubor and calor are features of histaminergic urticaria and tend to be more evident in histaminergic forms of angioedema than in nonhistaminergic forms.

Several receptors expressed on the endothelial cell membrane transduce intracellular signals that increase intracellular NO through various pathways. Thus, concomitant activation of receptors can eventually modulate endothelial permeability and consequent vasodilation and edema. In this sense, a recent observation by our group shows that clinical phenotypes of patients with hereditary angioedema due to $\mathrm{C} 1$ inhibitor deficiency (C1-INH-HAE) could be differentiated by serum levels of vascular permeability factors [12]. Envisaging a multifactorial response helps us to understand how genetic $\mathrm{C} 1-\mathrm{INH}$ deficiency, a congenital systemic defect, is expressed with the clinical phenotype of periodic angioedema. Periodic angioedema is mediated by excessive local generation of bradykinin that stimulates $\mathrm{B} 2$ receptors (BK-B2R), which in turn causes edema through the intracellular NO pathway [13]. Bradykinin is the end product of the contact activation system and kallikrein-kinin system (Figure 2) [14,15]. It is released when high-molecular-weight kininogen is cleaved by plasma kallikrein generated from its zymogen plasma prekallikrein [16]. The process is triggered/amplified by the presence of active coagulation factor XII (FXIIa), which is derived from the inactive precursor FXII. Plasma prekallikrein,
FXII, and high-molecular-weight kininogen form a complex in plasma and bind urokinase plasminogen activator receptor, cytokeratin 1, and $\mathrm{gClqR}$, which are located nearby on the endothelial cell membrane [17]. Upon initial activation by as yet unknown stimuli and in the presence of defective control due to C1-INH deficiency, the cell-bound complex generates excessive BK, which escapes inactivation and stimulates BK-B2R. Periodicity and localization of symptoms could be explained by the need for BK to encounter endothelial cells that are primed to respond by concomitant and as yet unknown stimuli [18]. This view is supported by evidence of an increase in levels of protein markers of endothelial cell activation during angioedema in patients with genetic C1-INH deficiency [19].

In summary, primary angioedema is caused by accumulation of a mediator that triggers specific receptors on a responsive endothelial surface. Binding generates intracellular NO, which disrupts the adhesiveness of adjacent endothelial cells, thus enabling accumulation of extracellular fluid. Various etiologic factors can lead to the release/accumulation of this mediator, thus accounting for nearly identical clinical phenotypes.

\section{Recognizing Angioedema Phenotypes}

The first questions asked by a doctor attending a patient presenting with the sudden appearance of a swollen lip (angioedema) include What did you eat?, Have you taken antibiotics or other drugs?, and Where have you been? The

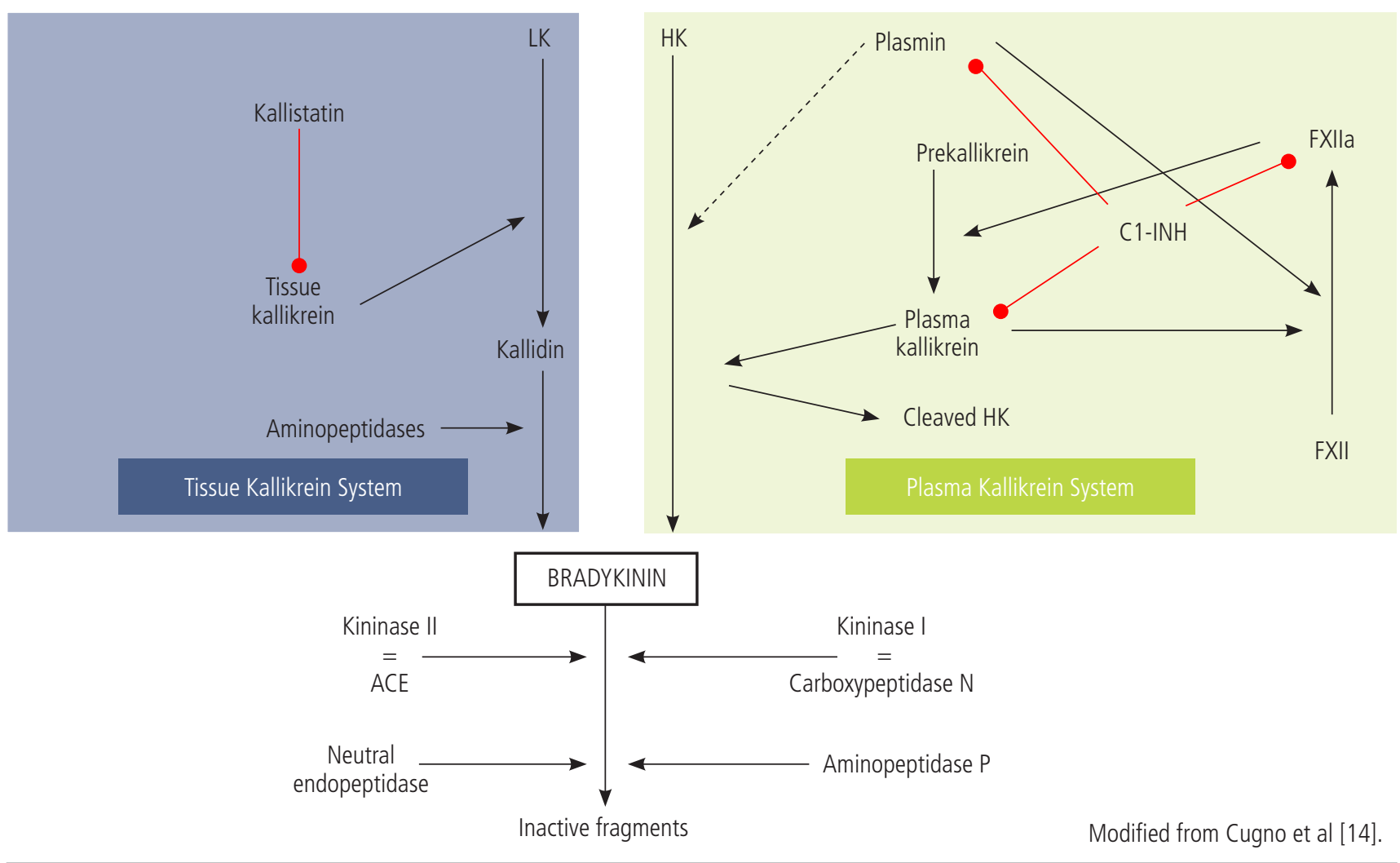

Figure 2. Contact activation system and kallikrein kinin system. LK indicates low-molecular-weight kallikrein; HK, indicates high-molecular-weight kallikrein; INH, inhibitor; ACE, angiotensin-converting enzyme. 
same is true if the swollen lip presents along with wheals (urticaria) all over the body. The questions asked by the doctor indicate that in both situations, the patient has experienced subcutaneous, localized edema, and allergy is the most common cause. If the patient recalls a potentially causative agent(s), the next step is an allergy workup; if not, the workup varies depending on whether the presentation was with or without wheals.

Angioedema symptoms per se indicate that allergy is the most common cause and histamine the most common mediator. Once allergy has been excluded and the symptoms recur, the condition needs to be framed based on the mediator, which may be histaminergic or nonhistaminergic. Histamine accounts for nearly all angioedema occurring with wheals and for most of those without wheals. Clinically, it is important to identify the mediator, because it drives therapy: in emergency situations, the frequency of the various forms may be the main criterion for choosing one treatment over another. In addition to epidemiology, a series of clinical characteristics can help to orient physicians towards the underlying mediator. Some of the most representative features of angioedema mediated by histamine and by bradykinin are reported in Table 1 .

The first classification of angioedema without wheals was reported by the HAWK group in 2014 and identifies 7 forms subdivided into 2 groups, hereditary and acquired. The criteria for considering angioedema hereditary are reported in Table 2. It is worth noting that hereditary angioedema can occur in the absence of a family history of angioedema. Within acquired and hereditary angioedema, specific forms are further distinguished by etiology, pathogenesis, or simply clinical phenotypes (Figure 3) [6].

\section{Acquired Angioedema}

The first form of acquired angioedema, idiopathic histaminergic acquired angioedema (IH-AAE), is of unknown origin, although it stops recurring with long-term antihistamine treatment. The characteristics of this form of angioedema are similar to those of urticaria (Table 3). As in wheals, erythema is fairly visible, and the lesion is more circumscribed than it is in nonhistaminergic forms. We previously reported data on a cohort of patients in whom angioedema without wheals was the most common form [20]. IH-AAE is diagnosed by excluding known causes of angioedema and resolution of symptoms with long-term antihistamine treatment. Acute symptoms usually respond to corticosteroids and epinephrine [21].

The most common form of recurring nonhereditary angioedema, even after high-dose antihistamine treatment, is associated with angiotensin-converting enzyme inhibitors (ACEI-AAE). ACEIs, which are used mainly for hypertension and heart failure, leave $0.5-1 \%$ of treated patients open to recurrent angioedema [22]. Symptoms do not appear directly on exposure, as in adverse drug reactions. They may start years after initiation of therapy and can recur with varying frequencies, from a few times a year up to every week [23]. When treatment with ACEIs is withdrawn, swelling stops or decreases considerably, although nearly $25 \%$ of patients who had their first angioedema attack during treatment continue to experience recurrences after discontinuation [24]. ACEI-AAE affects oral and perioral locations more often than other sites, with possible laryngeal involvement and risk of death [25]. BK was thought to be involved in this form of angioedema on the grounds that $\mathrm{ACE}$ is the main physiologic pathway of

Table 1. Histamine-Mediated and Bradykinin-Mediated Angioedema

\begin{tabular}{ll}
\hline Histamine-mediated & Bradykinin-mediated \\
\hline $\begin{array}{l}\text { Recognizable triggers such as insect stings, food, medications } \\
\text { Onset of swelling is rapid and often accompanied by urticaria } \\
\text { and itching }\end{array}$ & $\begin{array}{l}\text { Not accompanied by urticaria } \\
\text { History of recurrent swelling or unexplained, recurrent } \\
\text { abdominal pain }\end{array}$ \\
$\begin{array}{l}\text { Can affect any area of the body, although the facial area, throat, } \\
\text { and larynx are more common }\end{array}$ & $\begin{array}{l}\text { Family history of angioedema } \\
\text { Ongoing treatment with angiotensin-converting enzyme } \\
\text { Progression to anaphylaxis is possible }\end{array}$ \\
& $\begin{array}{l}\text { inhibitor } \\
\text { Progression to anaphylaxis is possible }\end{array}$
\end{tabular}

Table 2. Criteria for Hereditary Angioedema

Mendelian transmission of

- Clinical symptoms

$$
\text { or }
$$

- Serologic markers

- Functional $\mathrm{C} 1$ inhibitor $>50 \%$ of normal values or

- Disease-causing mutation

- C1 inhibitor gene (SERPING1)

- Coagulation factor XII gene (F12)
Table 3. Characteristics of Idiopathic Histaminergic Acquired Angioedema

Bridging between urticaria-angioedema syndrome and angioedema without urticaria

Clinical presentation similar to allergic angioedema

- Minor hives are frequently present

- Rule out history of allergy to food, drugs, insect stings, and vaccines

Diagnosis is confirmed by absence of recurrence with chronic antihistamine therapy at up to 4 times the dose recommended for allergic rhinitis 


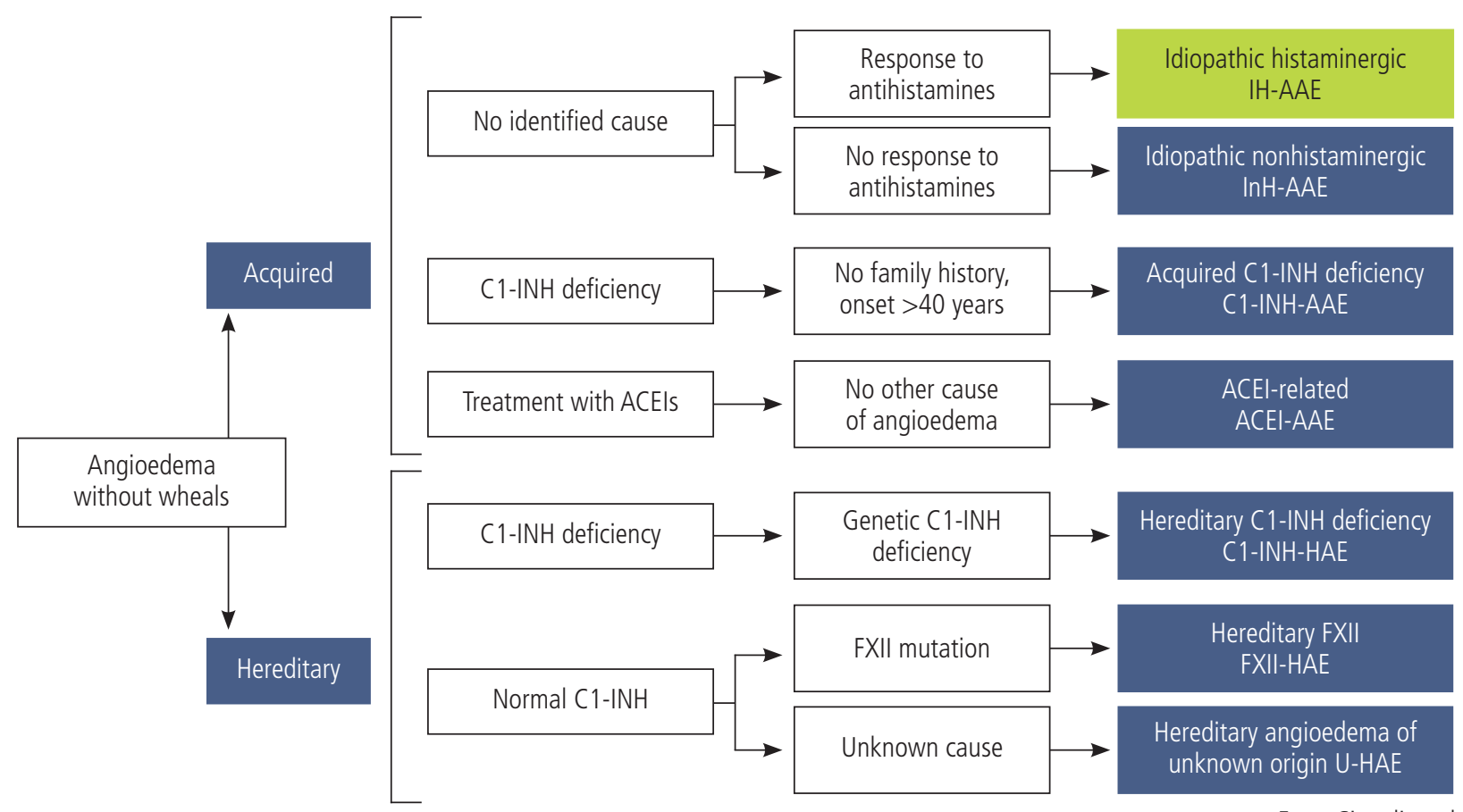

From Cicardi et al [6].

Figure 3. Recurrent angioedema without wheals. AAE indicates acquired angioedema; ACEl, angiotensin-converting enzyme inhibitor; INH, inhibitor; $H A E$, hereditary angioedema.

BK degradation [26]. This observation is further supported by evidence that levels of plasma BK increase in patients treated with ACEIs and particularly when patients receiving these drugs present symptoms of angioedema [27,28]. Moreover, a controlled study showed that the BK receptor antagonist icatibant reverses angioedema symptoms in ACEI-AAE [29].

Another well-defined form of AAE results from C1-INH deficiency (C1-INH-AAE), which does not depend on a genetic defect, but on protein consumption. It is clinically identical to the hereditary form, except that onset occurs after the fourth decade of life [30]. We recently reviewed a case series of 77 patients diagnosed since 1975 (Zanichelli et al, manuscript in preparation). Over this period, we diagnosed 1 case of C1-INH-AAE for every 8.8 cases of C1-INH-HAE, whose minimum prevalence in the Italian general population is 1:66000 [31]. The most important characteristic of this type of angioedema is the association with B-cell disorders, ranging from production of anti-C1-INH autoantibodies that can proliferate to appear as monoclonal bands of uncertain significance to malignant lymphoid proliferation of non-Hodgkin lymphoma (NHL) [32,33]. Autoantibodies bind and inactivate $\mathrm{C} 1-\mathrm{INH}$, thus rendering it deficient, while neoplastic B-cell tissues can directly consume C1-INH [34-36]. NHL was recorded in 33\% of the patients in our series; in $77 \%$, it took the form of splenic marginal zone lymphoma [37], a rare form of lymphoma ( $10 \%$ of all cases of NHL) in which neoplastic clones originate in postgerminal centers, ie, they derive from antigen-primed B cells. The extraordinarily high frequency (7-fold) of this lymphoma in C1-INH-AAE suggests that stimulation of the antigen ( $\mathrm{C} 1-\mathrm{INH}$ protein) by the immune system can contribute to lymphomagenesis in affected patients. Diagnosis of C1-INH-AAE requires functional

Table 4. Diagnosis of Idiopathic Nonhistaminergic Acquired Angioedema

Recurrent angioedema without wheals

No C1 inhibitor deficiency

No therapy with angiotensin-converting enzyme inhibitor

No causative agent(s)

No family history of angioedema

Absence of mutations in F12 gene

Persistence of recurrence of angioedema with continuous antihistamine treatment

Table 5. Clinical Picture of Hereditary Angioedema With C1-inhibitor Deficiency

- Recurrent, noninflammatory, nonpitting, self-limiting edema affecting

- subcutaneous tissue,

- gastrointestinal mucosa

- oropharyngolaryngeal mucosa

- Duration of each angioedema attack ranges between 1 and 5 days

- Frequency of recurrences varies between patients and also within the same patient

- From life-long asymptomatic to 3 attacks/week

- Mortality for hereditary angioedema is $>25 \%$ in undiagnosed patients 
levels of $\mathrm{C} 1-\mathrm{INH}$ below $50 \%$ of normal and parallel consumption of $\mathrm{C} 4$, as in $\mathrm{C} 1-\mathrm{INH}-\mathrm{HAE}$. Reduced $\mathrm{C} 1 \mathrm{q}$ levels and/or detectable plasma anti-C1-INH autoantibody levels are recorded in $70 \%$ of patients [30].

The third form of nonhistaminergic AAE is defined based on recurrence of angioedema without wheals and a series of negative findings that enable us to define it as idiopathic ( $\mathrm{InH}-$ AAE) (Table 4) [6]. Experimental evidence for BK mediating this type of angioedema is minimal and insufficient to draw conclusions on the responsible mediator [28].

\section{Hereditary Angioedema}

Various genetic mutations express the clinical phenotype of recurrent hereditary angioedema (HAE), which characteristically manifests without wheals. This phenotype causes significant personal, domestic, social, and occupational disability and exposes patients to the risk of death [38]. Mutations in 2 genes, the C1-INH gene (SERPING1) and factor XII gene $(F 12)$ have been shown to be responsible for 2 separate types of HAE, namely, C1-INH-HAE and FXII-HAE $[39,40]$. A third type, HAE of unknown origin (U-HAE), is not associated with SERPING1 or F12 mutations and does not involve plasma $\mathrm{C} 1-\mathrm{INH}$ deficiency. Moreover, its genetic cause is unknown [6]. All types of HAE share the same autosomal dominant pattern of inheritance. C1INH-HAE depends on heterozygous SERPING1 mutations that cause deficient production of the normal protein. Its biochemical diagnosis is based on antigenic and/or functional plasma $\mathrm{C} 1-\mathrm{INH}$ levels below $50 \%$ of normal. The clinical penetrance of this defect approaches $100 \%$, and angioedema stands out clearly in affected subjects (Table 5). For FXIIHAE, the diagnosis depends on the detection of specific mutations in F12, along with a personal or family history of recurrent angioedema without wheals. Low penetrance is characteristic of this form of angioedema: it is exceptional to find symptomatic males, and women have angioedema mostly in the presence of hyperestrogenemia, ie, during pregnancy or while taking birth control pills [41]. C1-INH deficiency leads to angioedema because it controls contact system activation; in the absence of $\mathrm{C} 1-\mathrm{INH}$, the contact system releases bradykinin to cause angioedema. Recent evidence supports the notion that F12 mutations also facilitate release of BK [42]. For U-HAE, the mechanism of angioedema formation remains unclear, and no significant data have been reported. Joseph et al [43] recently reported on the deficiency in plasma of plasminogen activator inhibitor 2 (PAI-2), a regulator of the fibrinolytic system, in patients with U-HAE. Since plasmin, the major enzyme of the fibrinolytic system, facilitates release of BK, defective regulation of this system could also link this type of $\mathrm{HAE}$ to excessive BK production.

Thus, family history is extremely important in patients presenting with angioedema without wheals. If positive, a diagnosis of HAE can be confirmed, but should be refined with further investigations aimed at identifying $\mathrm{C} 1$-INH deficiency or F12 mutations. Nevertheless, de novo mutants represent approximately $25 \%$ of index cases diagnosed with $\mathrm{C} 1-\mathrm{INH}-$ HAE [44], and the low penetrance of FXII-HAE has already been mentioned. Both conditions indicate that in angioedema without wheals, a negative family history is insufficient to rule out a hereditary form. All patients with otherwise unexplained angioedema without wheals should be screened for C1-INH deficiency and, in the case of women, we also recommend genotyping for $F 12$.

\section{Therapeutic Approach to Angioedema}

Histaminergic forms of angioedema are treated with antihistamines, corticosteroids, and epinephrine, as in other allergic mast cell-mediated disease. Initial evidence for the efficacy of the anti-IgE receptor omalizumab has recently been reported for angioedema of unknown origin $[45,46]$. The critical problem of treating angioedema arises in forms that are non-histamine-mediated. Of these forms, C1-INH-HAE, where $\mathrm{BK}$ is the recognized mediator, is the only one in which treatments targeting BK have been developed and are now licensed [47]. No controlled studies have been conducted and no treatments licensed for the remaining forms of angioedema without wheals.

The therapeutic approach to $\mathrm{C} 1-\mathrm{INH}-\mathrm{HAE}$ is based on the periodic nature of this disease, with strategies to revert or to prevent attacks by blocking release or activity of BK [48]. Acute attacks can be treated using $\mathrm{C} 1-\mathrm{INH}$ replacement, inhibition of plasma kallikrein, and blockade at the BK-B2Rs; prophylaxis is based on attenuated androgens and infusion of plasma-derived C1-INH concentrate (pd-C1-INH). There is widespread agreement on therapeutic goals (reduction in morbidity and mortality, prevention of recurrence, and improvement in quality of life). The initial approach involves on-demand treatment, which must be replaced by long-term prophylaxis (LTP) when it fails to significantly improve the patient's quality of life. Essential recommendations provided by guidelines are summarized in Table 6 [49]. A third therapeutic strategy, the so-called short-term/preprocedural prophylaxis, prevents occurrence of angioedema in high-risk situations that last for short periods [50].

Table 6. Treatment Guidelines for Angioedema With Hereditary C1 Inhibitor Deficiency

Patients should have medicines to treat acute attacks at home and should be trained to self-administer these medicines

All attacks, irrespective of location, are eligible for treatment as soon as they are clearly recognized by the patient

On-demand treatment for acute attacks should be the initial goal for all patients because it may reach the goals of HAE treatment by preventing death and reducing morbidity

Long-term prophylactic treatment is appropriate for patients in whom on-demand therapy is inadequate to minimize the suffering related to the disease

The circumstances under which on-demand therapy should be considered inadequate and the patient switched to long-term prophylaxis are controversial, and no consensus has been achieved

From Cicardi et al [49]. 


\section{Treatment of Acute Attacks}

Three C1-INH concentrates (Berinert, Cinryze, and Ruconest), the BK-B2R antagonist icatibant, and the kallikrein inhibitor ecallantide are licensed for treatment of attacks (ecallantide is only available in the USA). These medications proved to be significantly more effective than placebo (or tranexamic acid in the case of icatibant) in randomized, doubleblind, placebo-controlled clinical trials [51,55]. The relative efficacy of the drugs has not been compared in head-to-head trials. Guidelines recommend that, whenever possible, patients are instructed to self-administer on-demand treatments to maximize effect. Intravenous pd-C1-INH and subcutaneous icatibant are licensed for self-administration [56-59]. Ondemand therapy, particularly when self-administered, shortens the duration of attacks, leading to a dramatic reduction in the duration of angioedema symptoms [60]. The main difficulty is to educate and enable patients to treat attacks at onset in order to minimize disease-related disability. On-demand treatments have not been associated with significant adverse effects.

\section{Prophylaxis of Attacks}

In patients who experience frequent attacks and in whom on-demand therapy cannot adequately control disease, regular therapy to prevent episodes of angioedema should be considered. Attenuated androgens and pd-C1-INH have proven effective for LTP. The use of antifibrinolytic agents for LTP is supported by findings from randomized trials, although they are only used in specific populations owing to the significantly greater efficacy of the previous 2 approaches [50]. Given that breakthrough angioedema attacks may occur during LTP, all patients receiving this regimen must have on-demand therapy available for emergency situations.

Attenuated androgens increase plasma levels of C1-INH [61]. These drugs were first used for LTP in the 1970s and continue to play a major role in disease management because of their high efficacy [62]. The main concerns associated with their use are residual androgenic activity, liver toxicity, and atherogenic changes in the lipid profile, which require careful surveillance [63]. Therapy with attenuated androgens is highly problematic until after puberty and has been contraindicated during pregnancy and breastfeeding [64]. As adverse effects are dose-dependent, the minimal effective dose should be determined: treatment with danazol should be discouraged if doses exceeding $200 \mathrm{mg}$ per day are needed.

Cinryze is currently the only $\mathrm{C} 1-\mathrm{INH}$ concentrate approved for LTP. In a randomized controlled trial, doses of $1000 \mathrm{U}$ every 3-4 days reduced the frequency of attacks by $50 \%$ [54]. The main problem with this approach is that of venous access, which can limit use in some patients. A report from the United States Food and Drug Administration 3 years after registration in the USA revealed that Cinryze was associated with thrombotic events [65]. No such reports have since been published. It seems likely that initial thrombotic events were related to indwelling venous catheters that should not have been used to overcome venous access problems.

Although most HAE attacks occur spontaneously, it is well known that local trauma, stress, and surgical procedures can trigger angioedema. Physicians and patients are frequently concerned about the risk of swelling associated with upper airway manipulation, including dental care, but even minor procedures can induce angioedema from a few hours to a few days later. Thus, depending on the kind of procedure and on the patients' history of previous HAE attacks, a course of shortterm prophylaxis (STP) may be planned when appropriate. The efficacy of pdC1-INH in STP has been shown to be dosedependent in retrospective evaluations of dental procedures and other types of surgery [66,67]. Danazol may be considered an alternative to pd-C1-INH for STP. It needs to be started 5 days before and continued 2-3 days after the procedure [68].

\section{Off-label Treatments for Angioedema}

Other than C1-INH-HAE, no drugs have been licensed for the treatment of nonhistaminergic angioedema without wheals. Nevertheless, uncontrolled studies give an indication of the potential efficacy of some drugs for treatment of angioedema. Given the close similarity between C1-INH-HAE and acquired C1-INH deficiency, responses to various drugs have been similar. The main difference between the 2 conditions is that therapies based on C1-INH, C1-INH replacement, and attenuated androgens can become ineffective in a minority of patients (Zanichelli et al, manuscript in preparation). The reason for this finding is unclear. We speculate that it depends on the rate of C1-INH catabolism that underlies the disease and that in some patients it cannot be resolved. Icatibant can replace pd-C1-INH for acute treatment in nonresponsive patients [69], and the response to antifibrinolytic LTP appears to be better in C1-INH-AAE than in the hereditary form [70]. Angioedema symptoms in C1-INH-AAE patients can be controlled indirectly by treating the underlying lymphoma [71].

The only controlled trial outside C1-INH-HAE was that performed to test the efficacy of icatibant in reverting angioedema attacks in patients with ACEI-AAE [29]. The authors showed that the time to complete resolution of edema was significantly shorter with icatibant than with combination therapy with a corticosteroid and an antihistamine. This indication has not been registered, with the result that icatibant remains off-label for it.

Evidence of treatment efficacy in other types of hereditary or acquired nonhistaminergic angioedema with normal C1-INH is limited to case reports and uncontrolled small case series. Treatment of acute attacks has been approached with all BK-targeting drugs, although evidence of efficacy is too disperse to draw conclusions [72-75]. In our experience [20] and in that of Wintenberger et al [76], the efficacy of the antifibrinolytic agent tranexamic acid in preventing angioedema symptoms in patients with nonhistaminergic angioedema with normal $\mathrm{C} 1$ inhibitor levels appears to be good. For the same group of angioedema patients, Saule et al [77] also reported favorable experience with progestins, especially antigonadotropic progestins, to prevent attacks.

In recent years, we have made tremendous progress in defining new forms of angioedema and in developing treatments to target BK. In the near future, we hope to be able to adapt these and other approaches to the most relevant unmet need in the field, namely, nonhistaminergic angioedema with normal C1-INH levels. 


\section{Funding}

The authors declare that no funding was received for the present study.

\section{Conflicts of Interest}

The authors declare that they have no conflicts of interest.

\section{References}

1. Caccia S, Suffritti C, Cicardi M. Pathophysiology of Hereditary Angioedema. Pediatr Allergy Immunol Pulmonol. 2014;27:159-63.

2. Bohra S, Kariya PB, Bargale SD, Kiran S. Clinicopathological significance of Melkersson-Rosenthal syndrome. BMJ Case Rep. 2015;10.1136/bcr-2015-210138DOl

3. Axelrod S, Davis-Lorton M. Urticaria and angioedema. Mt Sinai J Med 2011;78:784-802.

4. Asero R, Tedeschi A, Marzano AV, Cugno M. Chronic spontaneous urticaria: immune system, blood coagulation, and more. Expert Rev Clin Immunol. 2016;12:229-31.

5. Wu MA, Perego F, Zanichelli A, Cicardi M. Angioedema Phenotypes: Disease Expression and Classification. Clin Rev Allergy Immunol. 2016:10.1007/s12016-016-8541-zDOI

6. Cicardi M, Aberer W, Banerji A, Bas M, Bernstein JA, Bork K, Caballero T, Farkas H, Grumach A, Kaplan AP, Riedl MA, Triggiani M, Zanichelli A, Zuraw B. Classification, diagnosis, and approach to treatment for angioedema: consensus report from the Hereditary Angioedema International Working Group. Allergy. 2014;69:602-16.

7. Ashina K, Tsubosaka Y, Nakamura T, Omori K, Kobayashi K, Hori M, Ozaki H, Murata T. Histamine Induces Vascular Hyperpermeability by Increasing Blood Flow and Endothelial Barrier Disruption In Vivo. PLoS One. 2015;10:e0132367.

8. Orsenigo $F$, Giampietro C, Ferrari A, Corada M, Galaup $A$, Sigismund S, Ristagno G, Maddaluno L, Koh GY, Franco D, Kurtcuoglu V, Poulikakos D, Baluk P,McDonald D, Grazia Lampugnani M, Dejana E. Phosphorylation of VE-cadherin is modulated by haemodynamic forces and contributes to the regulation of vascular permeability in vivo. Nat Commun. 2012;3:1208.

9. Bouillet L, Vilgrain I. VE-cadherin, a potential marker for endothelial cell activation during hereditary angioedema attacks. J Allergy Clin Immunol. 2014. DOI 10.1016/j. jaci.2014.04.016

10. Curry FR, Adamson RH. Vascular permeability modulation at the cell, microvessel, or whole organ level: towards closing gaps in our knowledge. Cardiovasc Res. 2010;87:218-29.

11. Duran WN, Breslin JW, Sanchez FA. The NO cascade, eNOS location, and microvascular permeability. Cardiovasc Res. 2010;87:254-61.

12. Loffredo S, Bova M, Suffritti $C$, Borriello F, Zanichelli A, Petraroli A, Varricchi G, Triggiani M, Cicardi M, Marone G. Elevated plasma levels of vascular permeability factors in $\mathrm{C} 1$ inhibitordeficient hereditary angioedema. Allergy 2016. DOI 10.1111/ all. 12862

13. Marceau F, Regoli D. Bradykinin receptor ligands: therapeutic perspectives. Nat Rev Drug Discov. 2004;3:845-52.
14. Cugno M, Zanichelli A, Foieni F, Caccia S, Cicardi M. C1inhibitor deficiency and angioedema: molecular mechanisms and clinical progress. Trends Mol Med. 2009;15:69-78.

15. Schmaier AH. The Contact Activation and Kallikrein/Kinin Systems: Pathophysiologic and Physiologic Activities. J Thromb Haemost. 2015.DOI 10.1111/jth.13194

16. Kaplan AP, Joseph K. Pathogenic mechanisms of bradykinin mediated diseases: dysregulation of an innate inflammatory pathway. Adv Immunol. 2014;121:41-89.

17. Mahdi F, Madar ZS, Figueroa CD, Schmaier AH. Factor $\mathrm{XII}$ interacts with the multiprotein assembly of urokinase plasminogen activator receptor, gC $1 \mathrm{qR}$, and cytokeratin 1 on endothelial cell membranes. Blood. 2002:99:3585-96.

18. Bossi F, Fischetti F, Regoli D, Durigutto P, Frossi B, Gobeil F, Jr., Ghebrehiwet B, Peerschke El, Cicardi M, Tedesco F.l. Novel pathogenic mechanism and therapeutic approaches to angioedema associated with C1 inhibitor deficiency. J Allergy Clin Immunol. 2009;124:1303-10.e4.

19. Kajdacsi E, Jani PK, Csuka D, Varga LA, Prohaszka Z, Farkas $\mathrm{H}$, Cervenak L. Endothelial cell activation during edematous attacks of hereditary angioedema types I and II. J Allergy Clin Immunol. 2014;133:1686-91.

20. Mansi M, Zanichelli A, Coerezza A, Suffritti C, Wu MA Vacchini R, Stieber C, Cichon S, Cicardi M. Presentation, diagnosis and treatment of angioedema without wheals: a retrospective analysis of a cohort of 1058 patients. J Intern Med. 2015;277:585-93.

21. Faisant C, Boccon-Gibod I, Mansard C, Dumestre Perard C, Pralong P, Chatain C, Deroux A, Bouillet L. Idiopathic histaminergic angioedema without wheals: A case series of 31 patients. Clin Exp Immunol 2016. DOI 10.1111/cei.12789

22. Kostis JB, Kim HJ, Rusnak J, Casale T, Kaplan A, Corren J, Levy E. Incidence and characteristics of angioedema associated with enalapril. Arch Intern Med. 2005;165:1637-42.

23. Byrd JB, Adam A, Brown NJ. Angiotensin-converting enzyme inhibitor-associated angioedema. Immunol Allergy Clin North Am. 2006;26:725-37.

24. Beltrami L, Zanichelli A, Zingale L, Vacchini R, Carugo S, Cicard M. Long-term follow-up of 111 patients with angiotensinconverting enzyme inhibitor-related angioedema. J Hypertens. 2011;29:2273-7.

25. Atalay E, Ozdemir MT, Cigsar G, Omurca F, Aslan N, Yildiz M, Gey ZB. Angiotensin Converting Enzyme Inhibitor-related Angioedema: A Case of an Unexpected Death. Iran J Allergy Asthma Immunol. 2015;14:642-5.

26. Wood SM, Mann RD, Rawlins MD. Angio-oedema and urticaria associated with angiotensin converting enzyme inhibitors. $\mathrm{Br}$ Med J (Clin Res Ed). 1987;294:91-2.

27. Pellacani A, Brunner HR, Nussberger J. Plasma kinins increase after angiotensin-converting enzyme inhibition in human subjects. Clin Sci (Colch). 1994;87:567-74.

28. Nussberger J, Cugno M, Cicardi M. Bradykinin-mediated angioedema. N Engl J Med. 2002;347:621-2.

29. Bas M, Greve J, Stelter K, Havel M, Strassen U, Rotter N, Veit J, Schossow B, Hapfelmeier A, Kehl V, Kojda G, Hoffmann TK. A randomized trial of icatibant in ACE-inhibitor-induced angioedema. N Engl J Med. 2015;372:418-25.

30. Zingale LC, Castelli R, Zanichelli A, Cicardi M. Acquired deficiency of the inhibitor of the first complement component: 
presentation, diagnosis, course, and conventional management. Immunol Allergy Clin North Am. 2006;26:669-90.

31. Zanichelli A, Arcoleo F, Barca MP, Borrelli P, Bova M, Cancian M, Cicardi M, Cillari E, De Carolis C, De Pasquale T, Del Corso I, Di Rocco PC, Guarino MD, Massaro I, Minale P, Montinaro V, Neri S, Perricone R, Pucci S, Quattrocchi P, Rossi O, Triggiani M, Zanierato $\mathrm{G}$, Zoli A. A nationwide survey of hereditary angioedema due to C1 inhibitor deficiency in Italy. Orphanet J Rare Dis 2015;10:11.

32. Jackson J, Sim RB, Whelan A, Feighery C. An IgG autoantibody which inactivates C1-inhibitor. Nature. 1986;323:722-4.

33. Cicardi M, Beretta A, Colombo M, Gioffre D, Cugno $M$, Agostoni A. Relevance of lymphoproliferative disorders and of anti-C1 inhibitor autoantibodies in acquired angio-oedema. Clin Exp Immunol. 1996;106:475-80.

34. Schreiber AD, Zweiman B, Atkins $P$, Goldwein $F$, Pietra G, Atkinson B, Abdou NI. Acquired angioedema with lymphoproliferative disorder: association of C1 inhibitor deficiency with cellular abnormality. Blood. 1976;48:567-80.

35. Alsenz J, Bork K, Loos M. Autoantibody-mediated acquired deficiency of C1 inhibitor. N Engl J Med. 1987;316:1360-6.

36. Malbran A, Hammer CH, Frank MM, Fries LF. Acquired angioedema: observations on the mechanism of action of autoantibodies directed against C1 esterase inhibitor. J Allergy Clin Immunol. 1988;81:1199-204.

37. Castelli R, Wu MA, Arquati M, Zanichelli A, Suffritti C, Rossi D, Cicardi $\mathrm{M}$. High prevalence of splenic marginal zone lymphoma among patients with acquired C1 inhibtor deficiency. Br J Haematol. 2016. DOI 10.1111/bjh.13908

38. Lumry WR, Castaldo AJ, Vernon MK, Blaustein MB, Wilson DA, Horn PT. The humanistic burden of hereditary angioedema: Impact on health-related quality of life, productivity, and depression. Allergy Asthma Proc. 2010;31:407-14.

39. Cicardi M, Zingale L, Zanichelli A, Pappalardo E, Cicardi B. C1 inhibitor: molecular and clinical aspects. Springer Semin Immunopathol. 2005;27:286-98.

40. Bork K, Wulff K, Witzke G, Hardt J. Hereditary angioedema with normal C1-INH with versus without specific F12 gene mutations. Allergy. 2015;70:1004-12

41. Bork K, Gul D, Hardt J, Dewald G. Hereditary angioedema with normal C1 inhibitor: clinical symptoms and course. Am J Med. 2007;120:987-92.

42. Bjorkqvist J, de Maat S, Lewandrowski U, Di Gennaro A, Oschatz C, Schonig K, . Defective glycosylation of coagulation factor XII underlies hereditary angioedema type III. J Clin Invest. 2015;125:3132-46.

43. Joseph K, Tholanikunnel BG, Wolf B, Bork K, Kaplan AP. Deficiency of plasminogen activator inhibitor 2 in plasma of patients with hereditary angioedema with normal C1 inhibitor levels. J Allergy Clin Immunol. 2016;137:1822-9 e1

44. Pappalardo E, Cicardi M, Duponchel C, Carugati A, Choquet $S$, Agostoni A, Tosi M. Frequent de novo mutations and exon deletions in the $\mathrm{C} 1$ inhibitor gene of patients with angioedema. J Allergy Clin Immunol. 2000;106:1147-54.

45. von Websky A, Reich K, Steinkraus V, Breuer K. Complete remission of severe chronic recurrent angioedema of unknown cause with omalizumab. J Dtsch Dermatol Ges. 2013;11:677-8.

46. Sands MF, Blume JW, Schwartz SA. Successful treatment of 3 patients with recurrent idiopathic angioedema with omalizumab. J Allergy Clin Immunol. 2007;120:979-81.
47. Wu MA, Zanichelli A, Mansi M, Cicardi M. Current treatment options for hereditary angioedema due to C1 inhibitor deficiency. Expert Opin Pharmacother. 2016;17:27-40.

48. Farkas H. Current pharmacotherapy of bradykinin-mediated angioedema. Expert Opin Pharmacother. 2013;14:571-86.

49. Cicardi M, BorkK, Caballero T, Craig T, Li HH, Longhurst H, Reshef A, Zuraw B; HAWK (Hereditary Angioedema International Working Group). Evidence-based recommendations for the therapeutic management of angioedema owing to hereditary C1 inhibitor deficiency: Consensus report of an International Working Group. Allergy. 2012;67:147-57.

50. Betschel S, Badiou J, Binkley K, Hebert J, Kanani A, Keith P, Lacuesta G, Yang B, Aygören-Pürsün E, Bernstein J, Bork K, Caballero T,Cicardi $M$, Craig T, Farkas $H$, Longhurst $H$, Zuraw B, Boysen H, Borici-Mazi R, Bowen T, Dallas K, Dean J, LangRobertson K, Laramée B, Leith $E$, Mace S, McCusker C, Moote B, Poon MC, Ritchie B, Stark D, Sussman G, Waserman S. Canadian hereditary angioedema guideline. Allergy Asthma Clin Immunol. 2014;10:50-68.

51. Zuraw B, Cicardi M, Levy RJ, Nuijens JH, Relan A, Visscher S, Haase G, Kaufman L, Hack CE. Recombinant human C1inhibitor for the treatment of acute angioedema attacks in patients with hereditary angioedema. J Allergy Clin Immunol. 2010;126:821-7.e14.

52. Cicardi M, Levy RJ, McNeil DL, Li HH, Sheffer AL, Campion M, Horn PT, Pullman WE. Ecallantide for the treatment of acute attacks in hereditary angioedema. N Engl J Med. 2010;363:523-31.

53. Cicardi $M$, Banerji $A$, Bracho $F$, Malbrán A, Rosenkranz B, Riedl M, Bork K, Lumry W, Aberer W, Bier H, Bas M, Greve J, Hoffmann TK, Farkas H, Reshef A, Ritchie B, Yang W, Grabbe J, Kivity S, Kreuz W, Levy RJ, Luger T, Obtulowicz K, Schmid-Grendelmeier P, Bull C, Sitkauskiene B, Smith WB, Toubi E, Werner S, Anné S, Björkander J, Bouillet L, Cillari E, Hurewitz $D$, Jacobson $\mathrm{KW}$, Katelaris $\mathrm{CH}$, Maurer M, Merk H, Bernstein JA, Feighery C, Floccard B, Gleich $G$, Hébert J, Kaatz $M$, Keith $P$, Kirkpatrick $C H$, Langton D, Martin L, Pichler C, Resnick D, Wombolt D, Fernández Romero DS, Zanichelli A, Arcoleo F, Knolle J, Kravec I, Dong L, Zimmermann J, Rosen K, Fan WT. Icatibant, a new bradykinin-receptor antagonist, in hereditary angioedema. N Engl J Med. 2010;363:532-41.

54. Zuraw BL, Busse PJ, White M, Jacobs J, Lumry W, Baker J, Craig T, Grant JA, Hurewitz D, Bielory L, Cartwright WE, Koleilat $M$, Ryan W, Schaefer $O$, Manning $M$, Patel P, Bernstein JA, Friedman RA, Wilkinson R, Tanner D, Kohler G, Gunther G, Levy R, McClellan J, Redhead J, Guss D, Heyman E, Blumenstein BA, Kalfus I, Frank MM. Nanofiltered C1 inhibitor concentrate for treatment of hereditary angioedema. N Engl J Med. 2010;363:513-22.

55. Craig TJ, Levy RJ, Wasserman RL, Bewtra AK, Hurewitz D, Obtulowicz K, Reshef A, Ritchie B, Moldovan D, Shirov T, Grivcheva-Panovska V, Kiessling PC, Keinecke HO, Bernstein JA. Efficacy of human C1 esterase inhibitor concentrate compared with placebo in acute hereditary angioedema attacks. J Allergy Clin Immunol. 2009;124:801-8.

56. Rizk C, Karsh J, Santucci S, Yang W. Self-administration of intravenous $\mathrm{C} 1$ esterase inhibitor in hereditary angioedema. CMAJ. 2013;185:791-2. 
57. Bygum A, Andersen KE, Mikkelsen CS. Self-administration of intravenous C1-inhibitor therapy for hereditary angioedema and associated quality of life benefits. Eur J Dermatol. 2009;19:147-51.

58. Aberer W, Maurer $M$, Reshef $A$, Longhurst $H$, Kivity S, Bygum A, Caballero T, Bloom B, Nair N, Malbrán A. Open-label, multicenter study of self-administered icatibant for attacks of hereditary angioedema. Allergy. 2014;69:305-14.

59. Maurer M, Aberer W, Bouillet L, Caballero T, Fabien V, Kanny G, Kaplan A, Longhurst H, Zanichelli A; I O S Investigators. Hereditary angioedema attacks resolve faster and are shorter after early icatibant treatment. PLoS One. 2013;8:e53773.

60. Zanichelli A, Mansi M, Azin GM, Wu MA, Periti G, Casazza G, Vacchini R, Suffritti C, Cicardi M. Efficacy of on-demand treatment in reducing morbidity in patients with hereditary angioedema due to C1 inhibitor deficiency. Allergy. 2016:70:1553-8

61. Gelfand JA, Sherins RJ, Alling DW, Frank MM. Treatment of hereditary angioedema with danazol. Reversal of clinical and biochemical abnormalities. N Engl J Med. 1976:295:1444-8.

62. Bork K, Bygum A, Hardt J. Benefits and risks of danazol in hereditary angioedema: a long-term survey of 118 patients. Ann Allergy Asthma Immunol. 2008;100:153-61.

63. Riedl MA. Critical appraisal of androgen use in hereditary angioedema: a systematic review. Ann Allergy Asthma Immunol. 2015;114:281-8 e7.

64. Farkas $H$, Veszeli N, Csuka D, Temesszentandrasi G, Toth $F$, Koszegi L, Varga L. Management of pregnancies in a hereditary angioedema patient after treatment with attenuated androgens since childhood. J Obstet Gynaecol. 2015;35(1):89-90.

65. Gandhi PK, Gentry WM, Bottorff MB. Thrombotic events associated with $\mathrm{C} 1$ esterase inhibitor products in patients with hereditary angioedema: investigation from the United States Food and Drug Administration adverse event reporting system database. Pharmacotherapy. 2012;32:902-9.

66. Bork K, Hardt J, Staubach-Renz P, Witzke G. Risk of laryngeal edema and facial swellings after tooth extraction in patients with hereditary angioedema with and without prophylaxis with C1 inhibitor concentrate: a retrospective study. Oral Surg Oral Med Oral Pathol Oral Radiol Endod. 2011;112:5864.

67. Farkas H, Zotter Z, Csuka D, Szabo E, Nebenfuhrer Z, Temesszentandrasi G, Jakab L, Varga L, Harmat G, Karádi I. Short-term prophylaxis in hereditary angioedema due to deficiency of the C1-inhibitor--a long-term survey. Allergy. 2012;67:1586-93.

68. Bowen T, Cicardi M, Farkas H, Bork K, Kreuz W, Zingale L, Varga L, Martinez-Saguer I, Aygören-Pürsün E, Binkley K, Zuraw B, Davis A 3rd, Hebert J, Ritchie B, Burnham J, Castaldo A,
Menendez A, Nagy I, Harmat G, Bucher C, Lacuesta G, Issekutz A, Warrington R, Yang W, Dean J, Kanani A, Stark D, McCusker C, Wagner E, Rivard GE, Leith E, Tsai E, MacSween M, Lyanga J, Serushago B, Leznoff A, Waserman S, de Serres J. Canadian 2003 International Consensus Algorithm For the Diagnosis, Therapy, and Management of Hereditary Angioedema. J Allergy Clin Immunol. 2004;114:629-37.

69. Zanichelli A, Badini M, Nataloni I, Montano N, Cicardi M Treatment of acquired angioedema with icatibant: a case report. Intern Emerg Med. 2011;6:279-80.

70. Agostoni A, Cicardi M. Hereditary and acquired C1-inhibitor deficiency: biological and clinical characteristics in 235 patients. Medicine (Baltimore). 1992;71:206-15.

71. Wu MA, Castelli R. The Janus faces of acquired angioedema: C1-inhibitor deficiency, lymphoproliferation and autoimmunity. Clin Chem Lab Med. 2016;54:207-14.

72. Bouillet L, Boccon-Gibod I, Ponard D, Drouet C, Cesbron JY, Dumestre-Perard C, Monnier N, Lunardi J, Massot C, Gompel A. Bradykinin receptor 2 antagonist (icatibant) for hereditary angioedema type III attacks. Ann Allergy Asthma Immunol. 2009:103:448

73. Cronin JA, Maples KM. Treatment of an acute attack of type III hereditary angioedema with ecallantide. Ann Allergy Asthma Immunol. 2012;108:61-2.

74. Boccon-Gibod I, Bouillet L. Safety and efficacy of icatibant self-administration for acute hereditary angioedema. Clin Exp Immunol. 2012;168:303-7.

75. Bork K. Diagnosis and treatment of hereditary angioedema with normal C1 inhibitor. Allergy Asthma Clin Immunol. 2010;6:15.

76. Wintenberger C, Boccon-Gibod I, Launay D, Fain O, Kanny G, Jeandel P, Martin L, Gompel A, Bouillet L. Tranexamic acid as maintenance treatment for non-histaminergic angioedema: analysis of efficacy and safety in 37 patients. Clin Exp Immunol. 2014;178(1):112-7.

77. Saule C, Boccon-Gibod I, Fain O, Kanny G, Plu-Bureau G, Martin L, Launay D, Bouillet L, Gompel A. Benefits of progestin contraception in non-allergic angioedema. Clin Exp Allergy. 2013:43:475-82.

\section{- Manuscript received May 23, 2016; accepted for publication June 9, 2016.}

\section{Marco Cicardi}

Ospedale Luigi Sacco

Via G.B. Grassi 74

20157 Milano

E-mail: marco.cicardi@unimi.it 